\title{
THE LEAF GREENNESS AND YIELD COMPONENTS OF PADDY PLANTS INFLUENCED BY BIOLOGICAL FERTILIZER WITH AND WITHOUT COMBINATION OF INORGANIC FERTILIZERS
}

\author{
Marianus Evarist Ngui \\ Department of Agronomy and Horticulture, \\ Bogor Agricultural University, Bogor, Indonesia
}

\author{
Dr. Sugiyanta \\ Department of Agronomy and Horticulture, \\ Bogor Agricultural University. Bogor, Indonesia
}

\author{
Dr. Maya Melati \\ Department of Agronomy and Horticulture, \\ Bogor Agricultural University, Bogor, Indonesia
}

\begin{abstract}
The use of biological fertilizer seems to be most important in creating environments for sustainable agriculture. This fertilizer is made up of living bacteria cells which depending on the soil conditions, are able to reproduce. In soil these bacteria have the greatest benefits for agricultural crops. They can increase the level of nitrogen in soil after converting the atmospheric nitrogen. Other species of these bacteria increase the availability of essential nutrient, Phosphorous. However, the availability of these two essential nutrients (nitrogen and phosphorous) in the soil is one factor in plant growth and yields. The second important factor is the ability of the roots to absorb these nutrients. In this aspect, the volume and type of roots of the respective plant also contribute significantly to plants growth as well as provision of expected yields. This study was carried on from September to December, 2018 at Sawah Baru, Bogor Agricultural University. The objectives were to observe the influence of biological fertilizer with and without combination of NPK and Urea fertilizers to enable rice plants to attain leaf green level which could produce expected paddy yields. The interaction effect between fertilizer treatments and the paddy varieties was also observed. Experiment design was two factor treatments arranged in a split plot. Fertilizer as main plot and paddy varieties as sub-plot laid in a Completely Randomized Block Design in 3 replications. The results showed significant differences in leaf green conditions and 1,000 grains weight of paddy.
\end{abstract}

Keywords - Nitrogen fixation; rhizosphere; root exudates; free-living bacteria.

\section{INTRODUCTION}

Nitrogen is an essential constituent of protein and chlorophyll (photosynthetic pigment). Furthermore, the nutrient $\mathrm{N}$ plays a fundamental role in agriculture by increasing crop yields [1]. Among of three essential nutrients for plants, it's the Nitrogen always insufficient in soils and is needed by high amounts. [2] have also stated most of paddy soils of the world are Ndeficient. Free-living bacteria (including saprophytes-bacteria living on plant residues, in close association with the rhizosphere and which live entirely within plants i.e., endophytes) e.g., Bacillus species may fix significant amounts of nitrogen $0-60 \mathrm{~kg} \mathrm{~N} \mathrm{ha}{ }^{-1}$ per year [3]. The process is dependent on high energy, 16 ATP, thus the microbes must find the source of energy either from crop residues or root exudates. Free-living nitrogen fixers that live only in aerobic conditions have evolved a specialized biochemical pathway for nitrogen fixation. According to [4], Bacillus species are among of these free-living nitrogen fixers. The bacteria are also well known to promote the release of Plant growth hormones, from their microbial activities [5]. They enhance biosynthesis of indole-3-acetic acid (IAA) wherein have a closely relationship with the availability of nutrients to plants [6]. The IAA produced by rhizobacteria also induce root morphogenesis and consequently enhance its (1) size and weight, (2) branch numbers and patterns and (3) the surface area of roots as reported in non-legumes [7]. Indole-3-aceticacid also essentially role in the origination and formation of adventitious roots [8-9], as well as in the enhancement of shoot development by the influence in cell division and differentiation. In this research the objectives were to observe the potential of biological fertilizer only or in combination with other chemical fertilizers to enhance leaf green color of rice plants which could facilitate the Rice plants to enable photosynthesis and produce expected yields. The second one was to observe the interaction effect of the fertilizer treatments with the paddy varieties. Two paddy varieties (Mekongga and IPB 3S) were used. Mekongga variety includes a new modern rice variety recognized by IRRI varieties and IPB $3 \mathrm{~S}$ rice variety is a rice variety resulted from crossing of modern and local varieties. The latter was created by a research team at Bogor Agricultural University at the end of 2014. 


\section{International Journal of Engineering Applied Sciences and Technology, 2021 \\ Vol. 5, Issue 10, ISSN No. 2455-2143, Pages 1-4 \\ Published Online February 2021 in IJEAST (http://www.ijeast.com)}

\section{MATERIALS AND METHODOLOGY}

\section{Materials}

One Indonesian Paddy variety (IPB 3S) and one Improved variety (Mekongga) were used during this research. The fertilizers were of three types, NPK; Urea; and Biological Fertilizer (BF)-contained ten strains of Bacillus Species ( $B$. catenulatus, B. cereus, B. drentensis, B. firmus, B. flexus, B. megaterium, B. niacin, $B$. subtilis, $B$. tequilensis and $B$. thuringiensis).

\section{Experimental Site and Duration}

This experiment was done at Sawah Baru $\left(6^{\circ} 33^{\prime} 50.4^{\prime \prime} \mathrm{S}\right.$ $106^{\circ} 44^{\prime} 09.9 " \mathrm{E}$, altitude 250 meter above the sea level) - IPB University, Darmaga, Bogor, Indonesia from September to December 2018.

\section{Experimental Design}

The experiment was two-factor treatments arranged in a split plot design with three replicates. The first factor was fertilizers amounts as main plot. In this, there were seven levels of fertilizer with and without combination of other fertilizer as shown in Table 1. The second factor was paddy varieties as sub plots.

Table 1. Applied Fertilizers (NPK, Urea and BF)

\begin{tabular}{ccccc}
\hline $\begin{array}{c}\text { Treatment } \\
\text { code }\end{array}$ & \multicolumn{3}{c}{$\begin{array}{c}\text { Levels of applied } \\
\text { fertilizers }\end{array}$} & $\begin{array}{c}\% \\
\text { of applied } \\
\end{array}$ \\
\cline { 2 - 4 } & $\mathrm{NPK}$ & Urea & $\mathrm{BF}$ & \\
$\mathrm{Kg} / \mathrm{ha}$ & $\mathrm{Kg} / \mathrm{ha}$ & $\mathrm{L} / \mathrm{ha}$ & \\
\hline Co (Control) & 0 & 0 & 0 & 0 \\
M4 & 75 & 37.50 & 4 & 25 \\
M3 & 150 & 75 & 4 & 50 \\
M2 & 225 & 112.50 & 4 & 75 \\
M1 & 300 & 150 & 4 & 100 \\
Only BF & 0 & 0 & 4 & 0 \\
M5 & 300 & 150 & 0 & 100 \\
\hline
\end{tabular}

Note: CF: Chemical Fertilizers. BF: Biological Fertilizer

\section{Experimental Procedures}

The field was prepared as normal flooded paddy fields. One, 14-days-old seedling from nursery was transplanted per hill at a planting distance of $25 \mathrm{~cm} X 25 \mathrm{~cm}$. The sub plot size was 5 $\mathrm{m} X 5 \mathrm{~m}$. The NPK fertilizer was applied in three times at 1,4 and 6 weeks after transplanting each time as much as $250 \mathrm{~g}$ per plot while Urea fertilizer applied at 1 and 4 WAT, 250 and $125 \mathrm{~g}$ per plot respectively as full recommended rate. The BF was applied as follows: $60 \mathrm{ml}$ was used during seeds soaking and sprayed direct on soils as much as $2.5 \mathrm{ml}$ per plot at 2, 4, 6 and 8 weeks after transplanting.

\section{Data Collection and Analysis}

During the growing period five plant samples were randomly selected and eye-marked in each plot for measurements and data collection. Leaf Greenness was measured at vegetative phase $(4,5,6,7,8$ and 9 weeks after transplanting) by using Leaf Color Chart. Panicle length was measured by Centimeter
Ruler. Thousand grains weight of paddy was determined by choosing using fingers the filled grains until 1,000 grains per plot then weighed by using electronic balance. Data were analysed with anova using SAS 9.4. Further comparison of means was done using Duncan Multiple Range Test (DMRT) at $\alpha=5 \%$.

\section{RESUlTS AND DisCUSSION}

\section{Leaf Greenness}

The leaf greenness is used as an indicator of plant leaf $\mathrm{N}$ status. Rice plants applied with $75 \%$ of CF + BF; and $100 \%$ of $\mathrm{CF}+\mathrm{BF}$ at 9 WAT were observed greenish and significantly different with other five fertilizer treatments. Only unfertilized plants (Co) observed yellowish green (implies there was $\mathrm{N}$ deficiency) and were significantly different with rice plants treated with only BF. This might be an indication there was continuous fixation of the $\mathrm{N}$-nutrient in soil by the Bacillus. Similarly, to Research done by [10], found strains of $B$. megaterium had ability of $\mathrm{N}_{2}$-fixing in paddy fields. On the other side applications of only BF; $25 \%$ of $\mathrm{CF}+\mathrm{BF} ; 50 \%$ of $\mathrm{CF}+\mathrm{BF}$; and $100 \%$ of only CF were not significantly different in the observed leaf green color. In all BF treated rice plants, the level of green color observed to delay in turning into yellowing stage as the plant leaf was getting old. Comparison on paddy varieties on leaf greenness during and after the vegetative growth were also noted. The IPB $3 \mathrm{~S}$ rice plants were the earliest to lose its green color after the vegetative stage has ended, but Mekongga variety delayed until 11 WAT, rice plants were still green in color.

Table 2. Leaf Greenness of rice plants in seven fertilizers treatments and two paddy varieties

\begin{tabular}{|c|c|c|c|c|c|c|c|c|}
\hline \multicolumn{3}{|c|}{$\begin{array}{c}\text { Combinations of } \\
\text { Fertilizers }\end{array}$} & \multicolumn{6}{|c|}{$\begin{array}{c}\text { Leaf Greenness } \\
\text { WAT }\end{array}$} \\
\hline NPK & Urea & $\mathrm{BF}$ & 4 & 5 & 6 & 7 & 8 & 9 \\
\hline$(\%)$ & $(\%)$ & \multicolumn{2}{|c|}{ (L/ha) } & \multicolumn{4}{|c|}{ LCC-Measurements } & \\
\hline 0 & 0 & 0 & $2.8 \mathrm{~b}$ & $2.9 \mathrm{~d}$ & $3.2 \mathrm{~d}$ & $3.2 \mathrm{~d}$ & $3.2 \mathrm{c}$ & $3.2 \mathrm{c}$ \\
\hline 25 & 25 & 4 & $3.0 \mathrm{a}$ & $3.38 b c$ & $3.5 \mathrm{bc}$ & $3.3 \mathrm{c}$ & $3.6 \mathrm{~b}$ & $3.6 \mathrm{~b}$ \\
\hline 50 & 50 & 4 & $3.0 \mathrm{a}$ & $3.4 a b c$ & $3.5 \mathrm{bc}$ & $3.4 \mathrm{c}$ & $3.6 \mathrm{~b}$ & $3.6 \mathrm{~b}$ \\
\hline 75 & 75 & 4 & $3.1 \mathrm{a}$ & $3.5 \mathrm{a}$ & $3.7 \mathrm{ab}$ & $3.6 \mathrm{~b}$ & $3.8 \mathrm{a}$ & $3.7 \mathrm{a}$ \\
\hline 100 & 100 & 4 & $3.1 \mathrm{a}$ & $3.5 \mathrm{a}$ & $3.7 \mathrm{a}$ & $3.7 \mathrm{a}$ & $3.8 \mathrm{a}$ & $3.7 \mathrm{a}$ \\
\hline 0 & 0 & 4 & $3.0 \mathrm{a}$ & $3.2 \mathrm{c}$ & $3.3 \mathrm{~cd}$ & $3.3 \mathrm{c}$ & $3.6 \mathrm{~b}$ & $3.6 \mathrm{~b}$ \\
\hline 100 & 100 & 0 & $3.1 \mathrm{a}$ & $3.6 \mathrm{a}$ & 3.6ab & $3.7 \mathrm{~b}$ & $3.6 \mathrm{~b}$ & $3.6 \mathrm{~b}$ \\
\hline \multicolumn{9}{|c|}{ Variety } \\
\hline \multirow{2}{*}{\multicolumn{2}{|c|}{$\begin{array}{l}\text { Mekongga } \\
\text { IPB 3S }\end{array}$}} & & 3 & 3.3 & 3.4 & 3.5 & 3.6 & 3.6 \\
\hline & & & 3 & 3.3 & 3.5 & 3.4 & 3.6 & 3.6 \\
\hline \multicolumn{2}{|c|}{ Interaction } & & ns & $\mathrm{ns}$ & ns & ns & $\mathrm{ns}$ & $\mathrm{ns}$ \\
\hline
\end{tabular}

Note: Numbers (Mean) marked by the same letter within the column shows not significantly different according to DMRT at $\alpha$ 5\%. WAT: Weeks After Transplanting. LCC: Leaf Color Chart. ns: not significantly different.

\section{Yield Components}

Number of grains per panicle varied from 197 to 203 . Similar to panicle length, no significance difference was observed due to applied fertilizer treatments. The range for panicle length was 27.5 to 28.6 (Table 3 ). Only IPB 3 S variety had a greater 


\section{International Journal of Engineering Applied Sciences and Technology, 2021 \\ Vol. 5, Issue 10, ISSN No. 2455-2143, Pages 1-4 \\ Published Online February 2021 in IJEAST (http://www.ijeast.com)}

Number of grains per panicle by $27.8 \%$ than the Mekongga variety and the difference was significantly. In panicle length also IPB $3 \mathrm{~S}$ variety was the longest by $15.4 \%$ than Mekongga.

The thousand grains weight of rice plants fertilized with only $\mathrm{BF}, 75 \%$ of $\mathrm{CF}+\mathrm{BF}$; and $100 \%$ of $\mathrm{CF}+\mathrm{BF}$ were heavier and significantly different than the grains weight of other four fertilizer treatments. High sink resulted from photosynthesis process might have been contributed to such heavier grains. Significant improvements on 1,000 grains weight due to application of formulations of Bacillus sp. on the growth of rice (Oryza sativa L.) was also reported by [11].

Only BF treated rice plants found significantly different in 1,000 grains weight as compared with only CF. This result, might be due to high status of initial soil organic matters (valued 4.2). So, the rice plants in BF treatments had more access to unlock essential nutrients from the organic matters as compared to only CF treated rice plants. However, strains of Bacillus contained in the $\mathrm{BF}$ have the ability to adjust soil $\mathrm{pH}$ [12] during the process of phosphate solubilization [13]. This process increases availability of phosphorous nutrient which is second important nutrient in plants and is the energy carrier during the photosynthesis.

Table 3. The average number of grains per panicle, panicle length and 1,000 grains weight of paddy in the combinations of fertilizers and two paddy varieties

\begin{tabular}{|c|c|c|c|c|c|}
\hline \multicolumn{3}{|l|}{ Treatments } & \multicolumn{3}{|c|}{ Parameter } \\
\hline Fertilizers & & & $\begin{array}{l}\text { Number } \\
\text { of grains/ } \\
\text { panicle }\end{array}$ & $\begin{array}{l}\text { Panicle } \\
\text { Length } \\
(\mathrm{cm})\end{array}$ & $\begin{array}{l}1,000 \text { grains } \\
\text { weight }(\mathrm{g})\end{array}$ \\
\hline NPK & Urea & $\mathrm{BF}$ & & & \\
\hline (\%) & $(\%)$ & $\left(\mathrm{L} \mathrm{ha}^{-1}\right)$ & & & \\
\hline 0 & 0 & 0 & 199.1 & 27.5 & $24.7 \mathrm{~b}$ \\
\hline 25 & 25 & 4 & 202.4 & 27.1 & $24.8 \mathrm{~b}$ \\
\hline 50 & 50 & 4 & 186.5 & 28.3 & $25.3 b$ \\
\hline 75 & 75 & 4 & 203.9 & 28.4 & $26.2 \mathrm{a}$ \\
\hline 100 & 100 & 4 & 191.3 & 28.0 & $26.5 \mathrm{a}$ \\
\hline 0 & 0 & 4 & 193.9 & 28.6 & $26.2 \mathrm{a}$ \\
\hline 100 & 100 & 0 & 197.8 & 27.5 & $25.2 \mathrm{~b}$ \\
\hline \multicolumn{6}{|l|}{ Varieties } \\
\hline Mekongga & & & $172.4 \mathrm{~b}$ & $25.9 b$ & $25.2 \mathrm{~b}$ \\
\hline IPB $3 S$ & & & $220.4 \mathrm{a}$ & $29.9 \mathrm{a}$ & $25.9 \mathrm{a}$ \\
\hline Interaction & & & ns & ns & ns \\
\hline
\end{tabular}

Note: Numbers (Mean) marked by the same letter within the column shows not significantly different according to DMRT at a 5\%. WAT: Weeks After Transplanting. ns: not significantly different.

\section{CONCLUSION}

The use of Biological fertilizer is highly emphasized to rice plant growers. Not only can improve paddy yields but also, protect agricultural fields from the consequences of chemical fertilizers in both water sources and food produces. Based on the results of this research, reduction by $50 \%$; 75 ; and $100 \%$ of CF-amounts if combined with BF was not observed significantly different on paddy leaf greenness as compared with plants treated with full recommended rates of CF. Furthermore, BF application in paddy fields are able to increase Nitrogen amount in the soil through fixation, whereby absorbed $\mathrm{N}$ by roots enhances green color of Paddy leaves. This research also concluded that, the use of only $\mathrm{BF}$; combination of $\mathrm{BF}$ with $75 \%$ and $100 \%$ of $\mathrm{CF}$ gave heavier 1,000 grains weight than the other four fertilizer treatments. Its therefore, has the potential of improving paddy yields. Lastly, the results found interaction between types of fertilizers and the paddy varieties used was not significantly different.

\section{REFERENCE}

[1] Massignam A.M., Chapman S.C., Hammer G.L., and Fukai S.(2009). Physiological determinants of maize and sunflower achene yield as affected by nitrogen supply. Field Crops Research, vol. 113, pp 256-267.

[2] Bashan Y., and de-Bashan L.E.(2010). How the plant growth-promoting bacterium Azospirillum promotes plant growth-a critical assessment. Advance in Agronomy, vol. 108, pp 77-136.

[3] Kahindi J.H.P., Woomer P., George T., Moreira, de S F.M., Karanja N.K., and Giller K.E.(1997). Agricultural intensification, soil biodiversity and ecosystem function in the tropics: the role of nitrogen-fixing bacteria. Appl. Soil Ecol, pp 55-76.

[4] Goswami D., Parmar S., Vaghela H., Dhandhukia P., and Thakker J. (2015). Describing Paenibacillus mucilaginosus strain N3 as an efficient plant growth promoting rhizobacteria (PGPR). Cogent Food \& Agriculture, vol.1, No.1, pp 1000714.

[5] Ahemad M., and Khan M.S. (2012). Effect of fungicides on plant growth promoting activities of phosphate solubilizing Pseudomonas putida isolated from mustard (Brassica campestris) rhizosphere. Chemosphere, vol,86 pp 945950 .

[6] Harman G.E. (2011). Multifunctional fungal plant symbionts: new tools to enhance plant growth and productivity. New Phytol, Vol. 189, No 3, pp 647-649.

[7] Dazzo F.B., and Yanni Y.G. (2006). The natural rhizobium-cereal crop association as an example of plantbacterial interaction. In: Uphoff N., Ball A.S., Fernandes E., Herren H., Husson O., Laing M., Palm C., Pretty J., Sanchez P., Sanginga N., Thies J. (eds) Biological approaches to sustainable soil systems. CRC, Boca Raton, FL, pp 109-127.

[8] Solano R.B., Garci'a J.A.L., Garcia-Villaraco A., Algar E., Garcia-Cristobal J., and Mañero F.J.G. (2010). Siderophore and chitinase producing isolates from the rhizosphere of Nicotiana glauca Graham enhance growth and induce systemic resistance in Solanum ycopersicum L. Plant Soil. Vol. 334, pp 189-197.

[9] Shafi J., Tian H., and Ji M. (2017). Bacillus species as versatile weapons for plant pathogens: a review, Biotechnology and Biotechnological Equipment, Vol. 31, No. 3, pp 446-459.

[10] Islam M.R., Sultana T., Cho J.C., Joe M.M., and Sa T.M. (2012). Diversity of free-living nitrogen-fixing bacteria associated with Korean paddy fields. Ann Microbiol. Vol. 62, pp 1643-1650. 
[11] Tinendung R., Puspita F., and Yoseva S. (2014). Test the formulation of Bacillus sp. as a growth booster for lowland rice (Oryza sativa L.). J. Online Student of Faculty of Agriculture Univ. Riau. Vol. 1, pp 1-15.

[12] Patel K., Goswami D., Dhandhukia P., and Thakker J.(2015).Techniques to study microbial phytohormones. In Maheshwari D.K. (Ed.), Bacterial metabolites in sustainable agroecosystem, pp. 1-27.

[13] Prasanna A., Deepa V., Murthy P.B., M. Deecaraman R., Sridhar R., and Dhandapani P. (2011). Insoluble Phosphate Solubilization by Bacterial Strains Isolated from Rice Rhizosphere Soils from Southern India. International Journal of Soil Science, Vol. 6, No. 2 pp 134-141. 